Marilia RAMOS

\title{
The impact of cultural capital on undergraduate students' performances in Brazil
}

\section{Introduction}

The article brings forth results obtained through research that verified the impact of exterior cultural elements in the performance of students at the undergraduate level in Brazil. The students in question, participated in the 2008 ENADE exam, which is coordinated by the Ministry of Education (MEC).

The Exame Nacional de Desempenho de Estudantes (National Student Performance Exam ENADE) evaluates the performance of undergraduate students, in their first and last year of university, in relation to the contents of the courses they are enrolled in. The National Student Performance Exam is, in addition to the analysis of courses and institutions; one of the means used to evaluate the quality of higher education in Brazil. Students' participation is mandatory and a requirement for graduation, as the exam is part of the academic record.

Created in 2004, the ENADE substituted the Exame Nacional de Cursos (National Course Exam, also known as Provao). Its objective is to analyze not the individual performances per se but to generate a general evaluation about the courses. Besides the scores of tests, ENADE measures the socioeconomic profile of students and their achievements on specific courses. Until 2009, a sample taken from the registered students was made by the Instituto Nacional de Estudos e Pesquisas Educacionais Anisio Teixeira (Inep).

The total number of students registered on the 2008 ENADE was 824,804 (among first year and graduating students); they were researched in the end of their first academic semester and in the end of their last academic semester.

The main research question was: How does familial and personal cultural capital of university students from Brazil, influence their academic grades? Considering a series of other factors such as economic conditions, what is the weight of university students' familial and personal cultural capital on undergraduate students' grades? Our hypothesis was based on Bourdieu and Passeron's idea that students with higher volume of personal and familial cultural capital and with greater access to information have a tendency of achieving superior performance in relation to those who possess less cultural capital. Through this research, our objective is to empirically verify the influence of undergraduate students' cultural capital in their performances, measured by the 2008 ENADE, taking into account the differences that may exists among students, as well as academic environments (different institutions) and professors, and if they live or not in rural areas. 
We consider that the relevance of this study relies in the fact that public policies in the area of higher education focus primarily on issues related to the academic environment; they are important policies, but don't take into account the reality of students outside the University.

It seems pertinent to promote studies that focus on questions related to cultural capital and issues of performance in academic institutions. In societies with high levels of inequality, like Brazil, where social mobility opportunities are scarce, it is justifiable to investigate if exterior variables reproduce social inequalities inside the universities.

According to the philosopher Zygmunt Bauman, education reproduces privileges instead of contributing to the betterment of society. He reminds us that, in the US $70 \%$ of university students come from higher classes, while only $3 \%$ are from the lower economic strata. Bauman contends that "this is a way of reaffirming social inequality", which is the topic of his book (August 2015).

One of education's duties is to guarantee to all peoples the opportunity of acquiring knowledge, which should then be used to benefit society. This objective however, is not achieved nor is it a priority in many places.

\section{Cultural Capital and the Reproduction of Inequalities}

There are many researches and sociological theories that help us navigate through the academic world. One of them seeks to explain the relationship between social inequalities and the performance of students. In this scenario, even if focusing on different aspects, it is important to note the work of Coleman (1997), Bourdieu (1982; 1998) and Bernstein (1997), among others. In a similar line of research, in Brazil Silva and Hasenbalg (2000), Barbosa (2009), Nogueira, Cunha,Viana and Resende (2009) are references in the topic.

The educational institutions were considered influential in the results presented by their students, but their social baggage was not excluded from the process.

In this paper we do not argue that the Educational Institution doesn't matter to students' academic performances. But we seek to shine light to the importance of certain characteristics students bring from home.

In relation to Cultural Capital, it is fundamental to take into account the different types it can be found. According to Bourdieu, a set of resources and abilities inherited from the dominant culture is considered incorporated cultural capital. Those are likes and esthetic dispositions originated from the dominants and translated through the habitus (systematic dispositions and perceptions frames). Bourdieu (2007, p. 76) highlights that the presence of cultural items in the household reinforces the education basis.

The other two types of cultural capital are the Acquired one: the possession of cultural items; and the institutionalized cultural capital, which is formed by the possession of academic titles. 
Specifically in the studied case, the incorporated cultural capital is the one which is acquired in the familial environment. It is part of secondary socialization, such as the habit of reading books, to appreciate art etc... The acquired cultural capital is the one materialized in the form of learning a second language, cultural belongings etc. and the institutionalized cultural capital is the one sanctioned by the State in the form of diplomas, qualifications and credentials (Bourdieu, 1998). There is an interesting relationship between incorporated cultural capital and institutionalized cultural capital, since in order to obtain both, economic capital is necessary.

The objectified cultural capital has some facets that are engendered only in their relationships with the corporate state. In its materiality, through books, paintings or sculptures, for example.

In addition, due to the direct contact with cultural heritage and a kind of family training, the young people of the privileged classes inherit knowledge, taste and distinctive arrangements that fit the requirements of institutionalized education.

\section{Dataset, Study Variables and Methodology}

ENADE's data set used in this research is from 2008 and was taken from MEC/INEP's website. The data set has the information of 824,804 students. 2008's data was chosen over 2010's (the most recent one available) because it utilizes a more complete socio-economic questionnaire, which was used in our research.

Certain questions are necessary in order to adequately measure the cultural capital of university students in Brazil, such as languages spoken (besides Portuguese) and at what level. What means do students use to access information and news; news papers, magazines and television, can be used as means to acquire knowledge and culture. The utilization of computers today, is a clear dividing factor since it is an important mean by which students can find additional information, and it is a useful tool in academic settings. In addition, cultural activities such as going to the theatre and cinema, attending concerts and shows are also taken into account.

All of the above criteria, are not mentioned in the 2010 ENADE but are present in the 2008 one. This clearly shows the importance of utilizing a more wholesome questionnaire when trying to understand how university students' cultural capital affects their academic performance, without being directly related to the academic environment.

In this study, the dependent variable is the proficiency of students in the ENAD 2008 and the main independent variable is cultural capital.

The proficiency of students is measured by the score obtained in the ENADE exam, which can range from 0 to 100; in the data set the overall average was 39.38 with a standard deviation of 14.60 .

The objectives of ENADE include the building of two kinds of measurements; one refers to the quality of the national education system, through the students' proficiency and the other 
relates to the components of the social context of students, which can be related to their performances.

In order to operationalize the complex dimensions of the cultural capital of the students, using the variables from the contextual questionnaires of 2008 ENAD, a cultural capital scale with 12 questions and answers was created ( see Table 1), by adding up their score a new point scale was made that goes from 0 to 33 points. The scale had 7 questions with four answer choices from 0 to 4 ( 28 points maximum) and 5 questions with two answer options, 0 and 1 (maximum 5 points). All responses were coded so that higher values correspond to responses that indicate greater cultural capital. Figure 1 below summarizes the items that composed the cultural capital scale.

Figure 1 Questions composing Cultural Capital scale

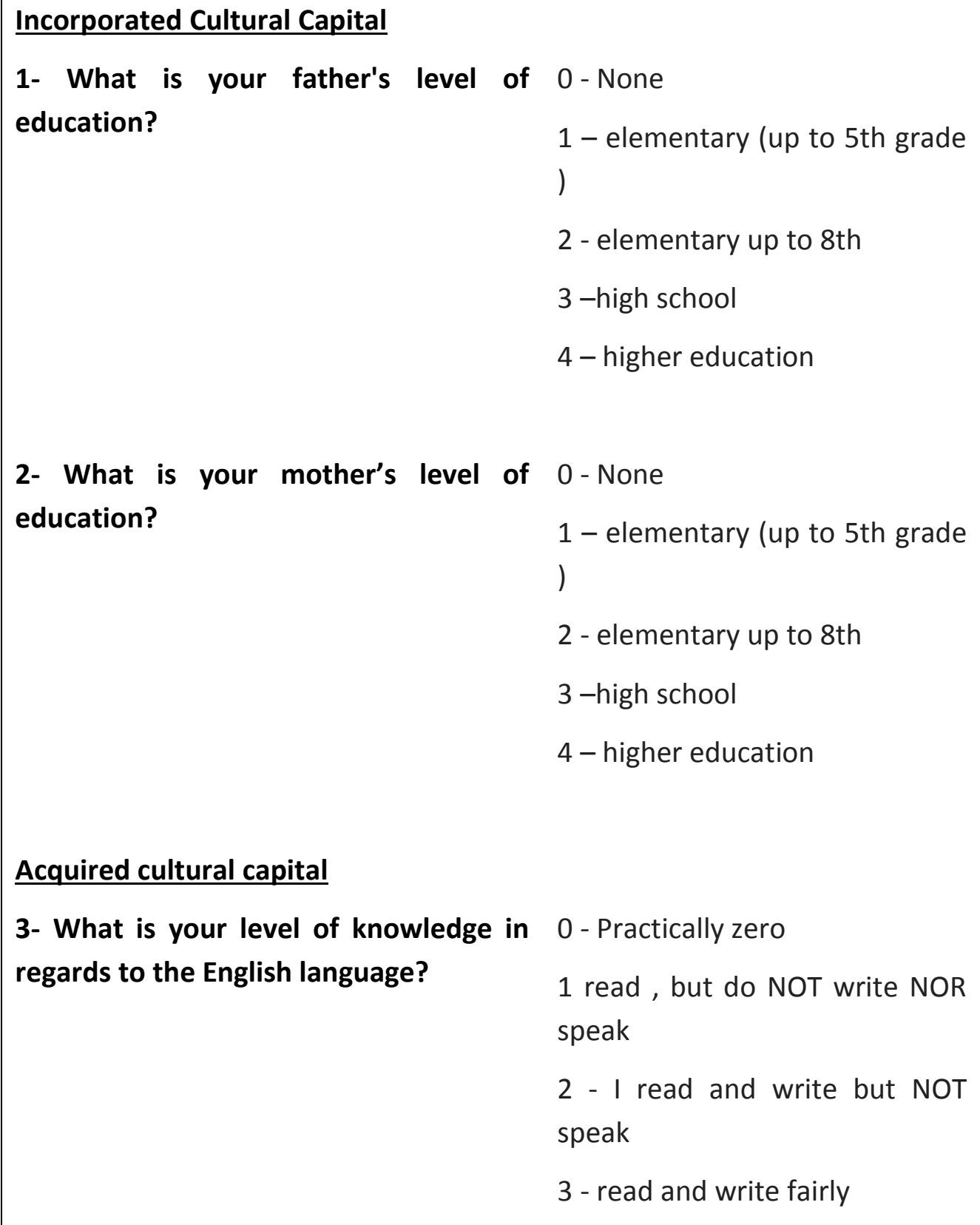


4 - I read, write and speak well

4- What is your level of knowledge in 0 - Practically zero regards to the Spanish language?

1 read, but do NOT write NOR speak

2 - I read and write but NOT speak

3 - read and write fairly

4 - I read, write and speak well

5- How often do you read the 0 -Never newspaper?

1 - Rarely

2 - ONLY on Sundays

3- Sometimes a week

4 - Daily

6- Do you participate in extracurricular 0 -No

cultural activities outside of HEI?

1-Yes

7-How often do you use a laptop 0 -Never computer?

1 - rarely

2 - Sometimes

3 - often

4 -always

8- How many books have you read this 0 -None year, not including mandatory books for University?

\section{1-2 Maximum}

2 -between 3:05

3 -between 6:08

4 -over 8 


\begin{tabular}{|c|c|}
\hline 9- Do you have access to internet? & $\begin{array}{l}0-\text { No } \\
1-Y e s\end{array}$ \\
\hline \multicolumn{2}{|l|}{ Institutionalized Cultural Capital } \\
\hline $\begin{array}{l}\text { 10- Which period of the day did you } \\
\text { most often have classes? }\end{array}$ & $\begin{array}{l}\text { 1- Day time } \\
\text { 0- Night time }\end{array}$ \\
\hline $\begin{array}{l}\text { 11- Which type of high school did you } \\
\text { attend for the majority of your studies? }\end{array}$ & $\begin{array}{l}\text { 1-private } \\
\text { 0-public }\end{array}$ \\
\hline 12- Type of education & 1- preparatory \\
\hline & 0-thecnical \\
\hline
\end{tabular}

The scale average found was 19.83 with a standard deviation of 4.10 The reliability coefficient (Cronbach's alpha) was 0.734 . The correlation between the score achieved in the ENADE and the cultural capital scale was 0.664 .

The model of analysis used had the measure of student proficiency in ENAD 2008 as its dependent variable, cultural capital scale as their main independent variable and the remaining as their control variables. The control variables refer to sex, marital status, work, income, number of kids, hours of studying, use of library, research activities and cohabitation.

The analytical strategy used was the multivariate linear regression; analysis of this kind allow for predictions of the effects of an independent variable to one dependent, taking into account the presence of other independent variables. The existence of these other independent variables works as a kind of control of the influence of the main independent variable. This is, given that students and schools do not have the same exact characteristics, we must take into account (or statistical language, "control") these differences so that we can capture the independent effect of cultural capital on student performance. Also, you can see how much of the variation in the dependent variable can be explained by the set of independent variables allocated in the analytical model.

First we present some descriptive analyses that allow us to view the profile of the students surveyed regarding cultural capital and also their average in ENADE by cultural capital indicators analyzed separately. Only after these descriptive analyses we present the results of our regression model.

The Brazilian university student's profile related to cultural capital 
Regarding the cultural capital levels and the student's sex, it was found by Table 1 below, that male students have significantly higher averages than female students.

Table 1 Sex

\begin{tabular}{lllll}
\hline & Sex & N & Mean & $\begin{array}{l}\text { Standard } \\
\text { Deviation }\end{array}$ \\
\hline \multirow{2}{*}{ Cultural k } & Male & 131109 & 20,4083 & 4,06029 \\
& Female & 159963 & 19,3680 & 4,07486 \\
\hline \hline
\end{tabular}

$p<=0,01$

Regarding marital status, as expected unmarried students have significantly higher scores than non single students, as can be seen in Table 2 below.

Table 2 Marital Status and cultural capital

\begin{tabular}{|c|c|c|c|c|}
\hline & Marital status & $\mathrm{N}$ & Mean & $\begin{array}{l}\text { Standard } \\
\text { Deviation }\end{array}$ \\
\hline \multirow{2}{*}{ Cultural k } & Single & 211039 & 20,4575 & 3,99656 \\
\hline & Not single & 80033 & 18,1993 & 3,91836 \\
\hline
\end{tabular}

$\overline{p<=0,01}$

Students who do not work have significantly higher averages of cultural capital in relation to students who work, as we can see in Table 3 below.

Table 3 Work and cultural Capital

\begin{tabular}{lllll}
\hline & No work=1 & N & Mean & $\begin{array}{l}\text { Standard } \\
\text { Deviation }\end{array}$ \\
\hline \multirow{2}{*}{ Cultural k } & No & 82693 & 20,6292 & 4,09525 \\
& Work & 208379 & 19,5221 & 4,06076 \\
\hline \hline
\end{tabular}

$\mathrm{p}<=0,01$

Students who self-declared as white, showed cultural capital averages significantly higher than students who self declared as black, as seen in Table 4, below. 
Table 4 Color and Cultural Capital

\begin{tabular}{lllll}
\hline & color & N & Mean & $\begin{array}{l}\text { Standard } \\
\text { deviation }\end{array}$ \\
\hline \multirow{2}{*}{ Cultural k } & White & 183070 & 20,2752 & 4,04972 \\
& No white & 108002 & 19,0932 & 4,08046 \\
\hline \hline
\end{tabular}

$p<=0,01$

Regarding cohabitation, those living with family members have significantly higher averages than those who do not, although the difference is not as significant according to what we see in Table 5 below.

Table 5 Cohabitation and Cultural Capital

\begin{tabular}{lllll}
\hline & Cohabitation & $\mathrm{N}$ & Mean & $\begin{array}{l}\text { Standard } \\
\text { deviation }\end{array}$ \\
\hline \multirow{3}{*}{ Cultural k } & Wihout & 47181 & 19,6756 & 4,13142 \\
& relatives & & & \\
& W/relatives & 243891 & 19,8678 & 4,09447 \\
\hline \hline
\end{tabular}

$\mathrm{p}<=0,01$

The relationship between cultural capital and performance in ENADE exam

As mentioned earlier, the correlation between scores in ENADE and the scale was 0.664. Analysis of the variables that make up the cultural capital scale separately showed us that those students whose fathers have higher level of education (higher) have an average mean grade in the ENADE greater than those whose fathers have lower educational levels. The same trend was found when the analysis was done for maternal education levels. These results were obtained by analysis of variance technique and the post hoc Tukey test. This shows that all differences in means of scores in all categories which involved parental and maternal education levels, were statistically significant at $p<=0.05$. The Tables 6 and 7 below show the results.

Table 6. Means ENADE's grades by father's education

\begin{tabular}{lrrr}
\hline \hline & $\mathrm{N}$ & Mean & \multicolumn{1}{c}{$\begin{array}{l}\text { Standard } \\
\text { deviation }\end{array}$} \\
\hline 0 - None & 20490 & 38,3972 & 13,69259 \\
$\begin{array}{l}1 \quad \text { elementary(up to 5th } \\
\text { grade ) }\end{array}$ & & & \\
\hline
\end{tabular}




$\begin{array}{llll}2 \text { - elementary Up to 8th } & 52222 & 39,4207 & 14,45594 \\ 3 \text {-High school } & 82380 & 39,6443 & 14,69426 \\ 4 \text {-Undergrad } & 51632 & 41,2605 & 15,25413 \\ \text { TOT } & 301269 & 39,9443 & 14,55830\end{array}$

Table 7. Means ENADE's grades by mother's education

\begin{tabular}{lccc}
\hline \hline & $\mathrm{N}$ & Mean & $\begin{array}{l}\text { Standard } \\
\text { deviation }\end{array}$ \\
\hline 0 - None & 16784 & 38,1931 & 13,70752 \\
$1 \quad$ elementary(up to 5th & & & \\
grade ) & 84337 & 30,2389 & 14,19523 \\
2 - elementary Up to 8th & 53038 & 39,5678 & 14,44600 \\
3 -High school & 88690 & 39,6389 & 14,69867 \\
4 -Undergrad & 59628 & 40,8354 & 15,11673 \\
TOT & 302477 & 39,9494 & 14,56019 \\
\hline \hline
\end{tabular}

With regard to knowledge of languages and the score in the ENADE, the research found that in spite of the fact Variance analysis were significant, differences in averages by level of language knowledge were not all statistically significant. Specifically in regards to knowledge of the English language, those who can read, write and speak well, had the highest average in the ENADE. However, there is no significant difference between those who declared they could read but not write nor speak and those who declared read, write and do not speak. Table 8 shows the averages of the notes in ENADE by level of knowledge in English.

Table 8. Means ENADE's grades by English Knowledge

\begin{tabular}{lccc}
\hline \hline & $\mathrm{N}$ & Mean & $\begin{array}{l}\text { Standard } \\
\text { deviation }\end{array}$ \\
\hline $\begin{array}{l}\text { - Practically zero } \\
118306\end{array}$ & 39,4544 & 14,58632 \\
$\begin{array}{l}1 \text { read, but NOT write and } \\
\text { speak NOR }\end{array}$ & & 39,1960 & 14,31391 \\
& & &
\end{tabular}




\begin{tabular}{|c|c|c|c|}
\hline $\begin{array}{l}2 \text { - I read and write but } \\
\text { NOT speak }\end{array}$ & 31076 & 39,0412 & 13,98744 \\
\hline 3 - read and write fairly & 71106 & 40,3255 & 14,35134 \\
\hline $\begin{array}{l}4 \text { - I read, write and speak } \\
\text { well }\end{array}$ & 28906 & 43,4327 & 15,43091 \\
\hline Total & 302580 & 39,9513 & 14,55724 \\
\hline
\end{tabular}

In relation to knowledge of Spanish, the highest averages of scores in the ENADE were found in the category of those who declared they could read and write reasonably. However, there is no significant difference between those who declared read but not write nor speak, and those who declared read, write and speak well. Table 9 shows the averages of the notes in ENADE by level of knowledge in Spanish.

Table 9 Means ENADE's grades by Spanish Knowledge

\begin{tabular}{|c|c|c|c|}
\hline & $\mathrm{N}$ & Mean & $\begin{array}{l}\text { Standard } \\
\text { deviation }\end{array}$ \\
\hline 0 - Practically zero & 86444 & 41,0175 & 14,74820 \\
\hline $\begin{array}{l}1 \text { read, but NOT write and } \\
\text { speak NOR }\end{array}$ & 17280 & 39,0831 & 14,38250 \\
\hline $\begin{array}{l}2 \text { - I read and write but } \\
\text { NOT speak }\end{array}$ & 43750 & 40,4042 & 14,58316 \\
\hline 3 - read and write fairly & 9721 & 41,6310 & 15,66886 \\
\hline $\begin{array}{l}4 \text { - I read, write and speak } \\
\text { well }\end{array}$ & 144973 & 39,1737 & 14,32304 \\
\hline Total & 302168 & 39,9532 & 14,55837 \\
\hline
\end{tabular}

$p<=0.05$

As for the frequency of books read per year and the average in ENADE those who reported reading more than 8 non-academic books a year had the highest average score in the ENADE as we can see in Table 10

Table 10. Average scores in ENADE and books read per year, not counting mandatory academic readings

N Mean Standard deviation 


\begin{tabular}{llll}
\hline None & 48887 & 36,3790 & 13,71161 \\
2 maximum & 98164 & 38,6469 & 14,10714 \\
Between 3-5 & 94489 & 41,1564 & 14,52929 \\
Between 6-8 & 27795 & 42,5601 & 14,72838 \\
Over 8 & 31183 & 44,0536 & 15,34576 \\
Total & 300518 & 39,9900 & 14,55763 \\
$\mathrm{p}<=0.05$ & & &
\end{tabular}

With regard to newspaper reading we did not find the expected difference would mean the highest score among those who read more often. In fact the biggest average score is in the group of those who reported reading newspaper only on Sundays. We think that today, young people tend to access information more through social networking sites and the internet than by newspaper reading itself. Table 11 illustrates the relationship between journal read and note the ENADE.

Table 11. Average scores in ENADE and newspaper reading frequency

\begin{tabular}{llll}
\hline \hline & N & Mean & $\begin{array}{l}\text { Standard } \\
\text { deviation }\end{array}$ \\
\hline 0 - Never & 13220 & 38,9057 & 14,61400 \\
1 - Rarely & 101065 & 40,3684 & 14,44171 \\
2 - ONLY TO Sundays & 22371 & 40,6236 & 14,74582 \\
3 Some times a week & 108237 & 40,1457 & 14,53025 \\
4 - Daily & 57041 & 38,8609 & 14,67123 \\
Total & 301934 & 39,9586 & 14,56010 \\
\hline \hline
\end{tabular}

$\mathrm{p}<=0.05$

With respect to computer use those who reported alwaus using had the highest Mean in ENADE scores as we can see in Table 12 below.

Table 12. Average scores in ENADE and computer use

\begin{tabular}{lll}
\hline \hline $\mathrm{N}$ & Mean & $\begin{array}{l}\text { Standard } \\
\text { deviation }\end{array}$ \\
\hline
\end{tabular}




\begin{tabular}{llll}
\hline Never & 5176 & 35,2337 & 13,32703 \\
Rarely & 10496 & 36,1452 & 13,18611 \\
Sometimes & 28143 & 37,9995 & 13,66176 \\
Often & 74759 & 39,9381 & 14,33829 \\
Always & 181846 & 40,6470 & 14,81018 \\
Total & 300420 & 39,9720 & 14,56312 \\
\hline \hline
\end{tabular}

$\mathrm{p}<=0.05$

With regard to the use of the Internet we observed that those who use it present greater averages in scores in the ENADE than those that do not. This result may support the findings above on the newspaper reading. Table 13 illustrates this information.

Table 13. Internet Access and Mean in ENADE Exam

\begin{tabular}{llll}
\hline \hline $\begin{array}{l}\text { Do you have Access to } \mathrm{N} \\
\text { the internet? }\end{array}$ & Mean & $\begin{array}{l}\text { Standard } \\
\text { deviation }\end{array}$ \\
\hline Yes & 278765 & 40,1579 & 14,59690 \\
No & 17625 & 38,3264 & 13,98987 \\
\hline \hline
\end{tabular}

$p<=0.05$

Regarding the type of school attending during high school, those who did all or most of their studies in private schools showed slightly higher averages than those who did most or all public school as we can see in Table 14 below.

Table 14. Average score in the ENADE test and type of school studied

\begin{tabular}{llll}
\hline \hline School & $\mathrm{N}$ & Mean & $\begin{array}{l}\text { Standard } \\
\text { deviation }\end{array}$ \\
\hline Private & 205455 & 39,6038 & 14,33371 \\
Public & 212062 & 39,1782 & 14,86507 \\
\hline \hline
\end{tabular}

$p<=0.05$

With regard to participation in cultural extracurricular activities, those who reported participating, had averages in the ENADE significantly higher than those who did not participate in accordance with Table 15 below.

Table 15. Average the test note ENADE and cultural activities 


\begin{tabular}{llll}
\hline \hline $\begin{array}{l}\text { Do you participate in N } \\
\text { cultural activities? }\end{array}$ & Mean & $\begin{array}{l}\text { Standard } \\
\text { deviation }\end{array}$ \\
\hline Yes & 279749 & 40,2203 & 14,56910 \\
No & 137768 & 37,6968 & 14,53933 \\
\hline \hline
\end{tabular}

$p<=0.05$

The average score in the ENADE also varies significantly among those who study mostly during the day compared to those who studied mostly at night. Those who studies during the Day had averages in the ENADE higher in those who reported studying in the night as shown in Table 16 below.

Table 16. Average score in the ENADE and turn of classes

\begin{tabular}{llll}
\hline \hline Turn & $\mathrm{N}$ & Mean & Standard deviation \\
\hline Day & 112929 & 40,7947 & 14,97673 \\
Night & 304588 & 38,8659 & 14,43347 \\
\hline \hline
\end{tabular}

$\mathrm{p}<=0.05$

Regarding the type of high school attended, those who made technical education had slightly higher average in ENADE that those who made preparatory school as seen in Table 17 below. This may be explained by the advent of federal technical schools, which have the highest level of quality.

Table 17. Average in ENADE exam and type of education attended

\begin{tabular}{llll}
\hline \hline Type of education & $\mathrm{N}$ & Mean & $\begin{array}{l}\text { Standard } \\
\text { deviation }\end{array}$ \\
\hline Preparatory & 202224 & 39,8310 & 14,55423 \\
& & & \\
Technical & 215293 & 38,9711 & 14,64525 \\
\hline \hline $\mathrm{p}<=0.05$ & & &
\end{tabular}




\section{The Conditioners to the students`academic performance on the ENADE exam}

We can see in our multivariate model, which included the cultural capital scale as the main independent variable and the other ones as control, that all variables were statistically significant. Specifically among the 12 variables included in the cultural capital model, cultural capital was among those with greater explanatory power (magnitude of the coefficient $b$ )

Specifically for each unit cultural capital score in the ENADE grew on average 1.22 points. Regarding the other variables with the greatest impact we highlighted in order of magnitude, participation in research activities was responsible for, on average 1.94 more points in ENADE than those who do not participate. Unmarried presented in average 1.87 points lower at ENADE than married. Those who do not attend library present in average 1.87 points lower at ENADE that those who use. Students from families with low income (less than 3 salaries to less than 10 minimum wages per month) have on average 1.42 points lower at ENADE than those with higher incomes (from 10 to more than 30 salaries per month). Finally those studying during the day have on average 1.02 points higher in ENADE that those who study at night.

Table 18. Multivariate Regression Model

\begin{tabular}{|c|c|c|c|c|c|}
\hline \multirow[t]{2}{*}{ Independent Variables } & & & & \multirow[t]{2}{*}{$\mathrm{t}$} & \multirow[t]{2}{*}{ Sig. } \\
\hline & B & Std. Error & Beta & & \\
\hline (Constant) & 29,856 & 231 & & 129,515 & 000 \\
\hline Cultural $\mathrm{K}$ & 1,221 & 207 &, 062 & 6,141 & ,000 \\
\hline white $=1$ & ,680 & ,057 & ,023 & 11,963 & ,000 \\
\hline single $=1$ & $-1,871$ & 080 &,- 057 & $-23,302$ & ,000 \\
\hline$w / o$ relatives $=1$ &,- 336 & 074 &,- 008 & $-4,528$ & ,000 \\
\hline No work=1 &,- 260 & ,065 &,- 008 & $-4,010$ & ,000 \\
\hline Low income $=1$ & $-1,423$ & ,057 &,- 048 & $-24,976$ & ,000 \\
\hline Number of kids &,- 853 & ,047 &,- 049 & $-18,275$ & ,000 \\
\hline Age & 160 & ,005 & ,086 & 32,549 & ,000 \\
\hline No use Library=1 & $-1,870$ & 109 &,- 032 & $-17,088$ & ,000 \\
\hline Hours of studying & 1,520 & ,025 & 114 & 60,214 & ,000 \\
\hline Research activity $=1$ & 1,947 & ,056 & ,065 & 34,709 & ,000 \\
\hline Day classes=1 & 1,022 & 061 & 033 & 16,759 & 000 \\
\hline
\end{tabular}

a. Dependent Variable: Grades on ENADE (0-100) $\quad$ R2 $=13,2$ 


\section{Conclusions}

After performing the statistical multivariate analysis, some variables are expressed among the most important to explain the students' performance. Participation in research, not going to the library, marital status, the number of hours of study, family income and cultural capital were characterized as variables with the greatest impact on student test scores.

The cultural capital occupied an important place among all the variables that made up the complete analytical model. Every unit that increases the cultural capital students' grades grow 1.22 points on average.

The gap analysis presented here is related to the individual components of each student, this macro analysis cannot (or should) reach with the available instruments. It was not possible to deepen the types of books accessed by students, the quality of education of the family, in short, an entire indisputable complexity as the specificities of each family, of each student. Also the daily relationships that trigger this or that ability, this or that incentive for studies, or the very facets of the obstacles that only a qualitative monitoring can light were absent in the course of this article.

Finally, it was proved that Bourdieu's theory is relevant, in the question of the influence of cultural capital in the proficiency of Brazilian undergraduate students. Even if the scope of all your settings should be qualified, as the University Institution also has its importance, not only reproducing inequalities, cultural capital still has an impact that needs to be taken into consideration mainly to help to build educational public policies.

\section{References}

- ANDRADE, Dalton; TAVARES, Heliton; VALLE, Raquel. Teoria da Resposta ao Item: Conceitos e Aplicações. SINAPE 2000.

- BARBOSA, M. L. O. \& Randall. Desigualdades Sociais e a Formação de Expectativas Familiares e de Professores. In: Caderno CRH, vol 41, 2004. Pp. 299-308.

- BARBOSA, Maria Ligia de Oliveira. Desigualdade e desempenho: uma introdução à sociologia da escola brasileira. Belo Horizonte: Argumentum, 2009.

- BERNSTEIN, Basil. Estrutura social, linguagem e aprendizagem. In: PATTO, Maria Helena Souza. Introdução à Psicologia Escolar. 3ạ Ed. São Paulo: Casa do Psicólogo, 1997. p. 145169.

- BONAMINO, Alicia; ALVES, Fátima; FRANCO, Crespo. Os efeitos das diferentes formas de capital no desempenho escolar: um estudo à luz de Bourdieu e de Coleman. Revista Brasileira de Educação, volume 15, número 45, setembro/dezembro 2010. Pp. 487-499.

- BOURDIEU, Pierre. A Distinção. Porto Alegre: Zouk, 2008.

A Reprodução. Rio de Janeiro: F. Alves, 1982. 
. Escritos de Educação: Pierre Bourdieu. Petrópolis: Vozes, 2007.

Los Herederos: Los Estudiantes y La Cultura. Buenos Aires: 2002.

O Poder Simbólico. Rio de Janeiro: Bertrand Brasil, 2010.

Os Usos Sociais da Ciência. São Paulo: UNESP, 2004.

Razões Práticas: Sobre a teoria da ação. Campinas: Papirus, 1996.

- BRASIL. MINISTÉRIO DA EDUCAÇÃO. Exame Nacional de Desempenho de Estudantes (ENADE), 2005 (Banco de dados). Brasil, 2006. In: Consórcio de Informações Sociais, 2007. Disponível em: <http://www.cis.org.br>. Accessed on 03/24/2011.

- COLEMAN, James. Social capital in the creation of human capital. In: Halsey et al. Education Culture Economy Society. Oxford: Oxford University Press, 1997.

FORQUIN, Jean Claude. Sociologia da Educação: Dez anos de pesquisa. Petrópolis: Vozes, 1995.

- GAMBOA, Luis; WALTENBERG, Fábio. Inequality of Opportunity in Educational Achievement in Latin America: Evidence from PISA 2006-2009. CEDE - Centro de Estudos sobre Desigualdade e Desenvolvimento, Discussion paper, n 49, july 2011.

- INSTITUTO NACIONAL DE ESTUdOS E PESQUISAS EDUCACIONAIS ANÍSIO TEIXEIRA. Relatório Nacional ENAD 2005. Brasília: INEP, 2006. 266 páginas.

- LAHIRE, Bernard. Sucesso Escolar nos Meios Populares: As Razões do Improvável. São Paulo: Ática, 1997.

- MORRISH, Ivor. Sociologia da Educação. Rio de Janeiro: Zahar, 1973.

- NOGUEIRA, Cláudio Marques; CUNHA, Maria Amália de Almeida; VIANA, Maria José Braga; RESENDE, Tânia de Freitas. A influência da família no desempenho escolar: estudo de dados da geração escolar 2005. In: Revista Contemporânea de Educação (UFRJ). Rio de Janeiro, vol 4, n 8, august/december 2009.

- ROSEMBERG, Fulvia. Race and gender inequalities in the Brazilian educational system. Paper presented at the Conference on Ethnicity, Race, Gender and Education, PREAL/Lima, Peru, 28/29, October 2002.

- SEABRA, Teresa. Desigualdades escolares e desigualdades sociais. Sociologia. [online]. jan. 2009, no.59 [cited 28 Junho 2011], p.75-106. Available in World Wide Web: $<$ http://www.scielo.oces.mctes.pt/scielo.php?script=sci_arttext\&pid=S0873$65292009000100005 \&$ Ing=pt\&nrm=iso >. ISSN 0873-6529.

- SILVA, Nelson do Valle; HASENBALG, Carlos. Tendências da Desigualdade Educacional no Brasil. In: Dados, vol. 43, n. 3, 2000, p. 423-445. 
- SILVA, Tadeu Tomaz da. 0 que produz e o que reproduz em educação: ensaios de sociologia da educação. Porto Alegre: Artes Médicas, 1992.

As contribuições de Bourdieu para a análise do campo educacional. In: Veritas, Porto Alegre, vol 41, n162, 1996. Pp. 243-248.

- SOARES, José Francisco; ALVES, Maria Teresa G. Relações raciais e desempenho escolar: as evidências do sistema da avaliação do ensino básico - SAEB. ANPOCS - XXVI Encontro Anual, Caxambu, MG, 2002.

- SOARES, José; COLLARES, Ana. Recursos familiares e o desempenho cognitivo dos alunos do ensino básico brasileiro. In: Dados - Revista de Ciências Sociais, Rio de Janeiro, vol 49, n 3, 2006. Pp. 615-650. 